\title{
The Contribution of Google Classroom Application and Motivation to The Learning Outcomes of Web Programming
}

\author{
Ade Mukhfir Guswara \\ Prodi Pendidikan Teknologi dan Kejuruan Fakultas Teknik Universitas Negeri Padang, Indonesia. \\ Email: ademg05@gmail.com
}

Wawan Purwanto

Jurusan Teknik Otomotif Fakultas Teknik UniversitasNegeri Padang, Indonesia. Email: wawanpurwanto@ft.unp.ac.id

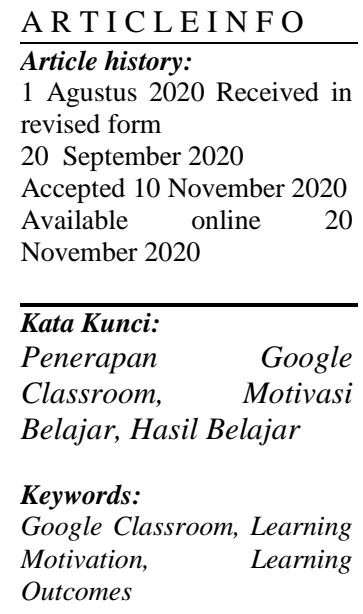

A R T I C L E I N F O

1 Agustus 2020 Received in Aised form

Accepted 10 November 2020

Penerapan Google

Classroom, Motivasi

Keywords:

Outcomes

\begin{abstract}
A B S T R A K
Pembelajaran online adalah salah satu pembelajaran yang paling efektif yang bisa digununkan dalam masa pandemic covid. Pembelajan online bisa dilakukan dengan Adalah bantu berupa google classroom. Penerapan metode ini masih mengalami pro dan kontra. Oleh sebab itulah maka dirumuskan tujuan penelitian adalah untuk mengkaji seberapa besar kontribusi penerapan Google Classroom dan motivasi belajar terhadap hasil belajar pemrograman web. Jenis penelitian adalah deskriptif korelasional. Populasi dalam penelitian berjumlah 64 siswa. Teknik pengambilan sampel digunakan simple random sampling didapatkan sampel 39 siswa. Pengumpulan data dengan angket dan dokumentasi. Angket untuk mengumpulkan data penerapan Google Classroom dan motivasi belajar. Dokumentasi untuk mengambil data hasil belajar. Uji prasyarat analisis dengan uji normalitas, linieritas, dan multikolineritas. Metode analisis data digunakan regresi sederhana dan regresi berganda. Hasil penelitian adalah: (1) Terdapat kontribusi positif dan signifikan penerapan Google Classroom terhadap hasil belajar sebesar $29,60 \%$. (2) Terdapat kontribusi positif dan signifikan motivasi belajar terhadap hasil belajar sebesar 20,30\%. (3) Terdapat kontribusi positif dan signifikan penerapan Google Classroom dan motivasi belajar secara bersama-sama terhadap hasil belajar sebesar $49,90 \%$.
\end{abstract}

\section{A B S T R A C T}

Online learning is one of the most effective lessons that can be used during the Covid 19 pandemic. Online learning can be done with google classroom. The application of this method is still experiencing pros and cons. For this reason, the research objective was formulated to examine how much the contribution of the Google Classroom application and learning motivation of web programming learning outcomes. This research is descriptive correlational. The population in the study were 64 students. The sampling technique used simple random sampling, obtained 39 students as sample. Data collection using questionnaires and documentation. Questionnaire to collect data on Google Classroom application and learning motivation. Documentation to retrieve learning outcome data. The prerequisite analysis test was tested for normality, linearity, and multicollinearity. The data analysis method used simple regression and multiple regression. The study results are: (1) There is a positive and significant contribution of the Google Classroom application to learning outcomes $(29.60 \%)$. (2) There is a positive and significant contribution of learning motivation to learning outcomes (20.30\%). (3) A positive and significant contribution to the implementation of Google Classroom and learning motivation to learning outcomes was $49.90 \%$.

\section{Introduction}

Online learning is one of the lessons that are currently the most appropriate alternative that can be done to prevent the spread of covid-19. Covid-19 is a virus that attacks the human respiratory system. It spread through humans within a week, and it can changes in 100 countries (Remuzzi \& Remuzzi, 2020). The existence of Covid-19 affects the health sector and all aspects of human life (Wong et al., 2020). One of the fields that are changing and must be ready to change is education. Learning that was initially carried out face-to-face is directly transformed into online learning. (Chang et al., 2020; Khachfe et al., 2020; Panesar et al., 2020), All learning activities such as comparative studies, visits, seminars, and conference activities have been postponed or even canceled (Mishra et al., 2020; Oyedotun, 2020; Patricia, 2020; Sahu, 2020). At the beginning of the emergence of online learning, there were many pros and cons from education experts. It was considered that online learning reduced students' ability to interact (Edwards et al., 2012; O’Doherty et al., 2018). Several different education experts give different opinions. Online learning provides students opportunities to explore the broadest possible information, understand abstract material, and develop collaborative learning, reasoning, and problem-solving 
activities (Arnott \& Yelland, 2020). For now, online learning is one of the most appropriate solutions given to students during a pandemic. Online learning provides opportunities for students to share opinions and learn to be more independent without time and space limits that are more flexible (Hwang et al., 2020; Kkese, 2020; LageCala et al., 2020). Tools used in the online learning process are google meet, google room, google classroom, WA, and social media (Chang et al., 2020).

WA currently dominates online learning. All activities carried out from assigning assignments and collecting tasks are all done through WA. Currently, the easiest tool to use in the learning process is with the help of WA. All activities carried out, such as giving assignments, are given via WhatsApp's. If the students still do not understand, the teacher will also add by sending videos or making WhatsApp's Video Calls with students. Giving assignments makes it easier for students via WhatsApp's messages and assignments. It also sent via WhatsApp's, and usually, students take photos of the assignment and send it to the teacher (Anugrahana, 2020). Online learning via WhatsApp in elementary schools tends to be ineffective (Daheri et al., 2020). Less effective learning with the help of Wa will certainly have an impact on student learning outcomes.

Learning outcomes are all forms of the learning process results, both knowledge, skills, and attitudes. Learning outcomes are strongly influenced by students' emotions in the learning process (Roh et al., 2020). Quality learning outcomes will be realized if the learning process carried out provides opportunities for students to be more active in learning and discovering their knowledge. Students who are more active in the learning process will form a more meaningful learning atmosphere. Meaningful learning will be generated if students gain experience and develop emotional intelligence. The learning process is carried out with a constructivism approach (Angela, 2014; Kostiainen et al., 2018). Many students have not reached the minimum completeness criteria based on existing data about learning outcomes in web programming subjects. The students who have 90-100 is $0 \%$, the students who have $80-89$ is $4 \%$ in XII RPL A and 5\% XII RPL B. The students who have 7579 is $32 \%$ XII RPL A and $40 \%$ XII RPL B and the students who have $<69 \%$ is $64 \%$ XII RPL A and 55\% XII RPL B. Several factors influence learning outcomes. Both factors that come from students and outside themselves, which greatly affect student learning outcomes, are the learning facility.

Learning facilities needs in the teaching and learning process, both mobile and immobile, so that the achievement of educational goals can run smoothly, regularly, effectively, and efficiently to achieve optimal learning outcomes (Cynthia et al., 2015). The use of facilities in teaching and learning activities is very important because learning facilities include all the tools that support student learning activities (Wulandari, 2019). Especially at this time, the online learning process requires smartphones, laptops, or tablets to access information (Sourial et al., 2018). In addition to learning facilities that affect student learning outcomes is motivation.

Motivation to learn is an impulse that enables students to act or do something (Mulyasih \& Suryani, 2016). Motivation to learn is essential for learning to be actively involved in learning and make it easier for students to understand the material (Pratiwi et al., 2019; Sjukur, 2013). Maximizing motivation will maximize the learning outcomes that can be achieved (Shaleh, 2016). Motivation can play a role in strengthening learning if a child who is learning is faced with a problem that determines the solution and can only be solved thanks to the help of things that have been passed (Novianti et al., 2020). Learning motivation has a positive and significant relationship with student learning outcomes (Saputra et al., 2018). The role of the teacher here is very influential on student learning motivation. The main factor is the key to success in the learning process (Prananda \& Hadiyanto, 2019). Therefore, one of the important roles of teachers in the learning process is to choose the right method in the online learning process.

One of the teacher learning methods in online learning is the application of Google Classroom. Google Classroom is an online learning application that can be used by all spheres of education that helps teachers and students share files in teaching and learning activities (Mahitsa \& Mahardini, 2020). Google classroom is effectively applied in the learning process and positively affects mathematical thinking skills (Santosa et al., 2020). Rahmanto \& Bunyamin, (2020) stated that Google classroom is effectively used in educational administration practicum subjects because students and lecturers are easy to access according to the needs. Permata \& Bhakti, (2020) stated that Google Classroom is less effective in learning physics. However, it has been effective in learning virtual classes and can be used as a learning application during the Covid-19 pandemic.

Based on this statement, it can be said that it is necessary to conduct a study related to google classroom and learning motivation. This research examines the google classroom application's contribution and learning motivation to web programmers' learning outcomes. Knowing the google classroom application and learning motivation to learning outcomes is one of the studies that can be used for decision-making and finding the best solutions in the online learning process. 


\section{Method}

This research is a descriptive correlational research type because it connects several phenomena, factors that affect learning outcomes. This study's population was the twelfth-grade students of Software Engineering at SMK Negeri 3 Pariaman in the 2020/2021 school year, which consisted of two study groups with 64 students. The sampling technique in this study was carried out using the formula from Taro Yamane. The sample obtained from the calculation of the formula was 39 respondents. This study uses a research instrument in the form of a questionnaire to obtain information about the application of Google Classroom and student learning motivation. At the same time, the documentation method is used to obtain information about learning outcomes. The statement used as a data collection tool is declared appropriate or unfit. The data collection tool will be known through the instrument's validity and reliability tests. The test criterion is valid or not each item is by comparing $\mathrm{r}$ count with $r$ table at the $5 \%$ significance level. If the $r$ count is smaller than the $r$ table, it is said to be invalid.

Reliability refers to the level of reliability of something. The correlation coefficient is significant or not used distribution ( $\mathrm{r}$ table) for $\alpha=0.05$. Then make a decision comparing $r_{11}$ with $r$ table. The decision rule if $r_{11}>$ $\mathrm{r}$ table means reliable and if $\mathrm{r}_{11}<\mathrm{r}$ table means it is not reliable.

The prerequisite analysis test was conducted to determine whether the research data for each collected variable met the requirements for use in hypothesis testing. The prerequisite tests carried out include:

\section{Normality test}

The normality test was carried out to determine whether the data for each variable was normally distributed or not. The normality test was carried out by the One Sample Kolmogorov Smirnov method. For decision-making, whether the data is normal or not is based on the significance score (Asymp Sig 2-tailed). If the significance is $\leq 0.05$, the conclusion is that the data was not normally distributed. If the significance $>0.05$, the data is normally distributed.

\section{Linearity Test}

Linearity test used to determine the data's linearity, whether two variables have a linear relationship or not. Two variables are said to have a linear relationship if the sign on the line Deviation for Linearity is more than 0.05 or by comparing the calculated F score listed in the ANOVA Table from the SPPS application's output with the $\mathrm{F}$ table. If the $\mathrm{F}$ score is smaller than the $\mathrm{F}$ table at the 5\% significance level. In that case, there is a linear relationship between the two variables.

\section{Multicollinearity Test}

A multicollinearity test is conducted to determine whether there is multicollinearity or not. The multicollinearity test method used is by looking at the Tolerance and Variance Inflation Factor (VIF) scores. A regression model is free from multicollinearity if it has a Tolerance score of more than 0.1 and a VIF score of less than 10 .

\section{Hypothesis testing}

Simple regression analysis techniques are used to determine the independent variable's effect on the dependent variable $(\mathrm{Y})$. Test the significance with the t-test. The $\mathrm{t}$ score is then compared to the table score with a significance level of $5 \%$. If $t$ count $>t$ table, the independent variable with the dependent variable has a significant effect. Conversely, if $t$ count $<t$ table, the independent variable's effect on the dependent variable is not significant. Multiple regression analysis is followed if there is a relationship between two independent variables $(\mathrm{X})$ or more together with the dependent variable $(\mathrm{Y})$. Test the significance of multiple regressions with the $\mathrm{F}$ test. The $\mathrm{t}$ score compared to the $\mathrm{F}$ table score with $5 \%$ significance level. If $\mathrm{F}$ count $>\mathrm{F}$ table, the independent variable with the dependent variable has a significant effect. Conversely, if $t$ count $<t$ table, the independent variable's effect on the dependent variable is not significant.

\section{Result and Discussion}

Data on Google Classroom's application was obtained from a questionnaire consist of 19 statements with five alternative answers, 5 for the highest score and 1 for the lowest score. The data obtained from the questionnaire for the application of Google Classroom variables shows that the highest score is 90 from the highest possible score of 95 . The lowest score is 40 , from the lowest possible score of 19 . The results of the analysis using the IBM SPSS Statistics 24 application show the mean (M) amounting to 64.23; median (Me) of 65.00; mode (Mo) of 65 and standard deviation (SD) of 15.010. The frequency distribution shows that the greatest frequency for applying Google Classroom scores is at intervals of 64-71 as many as ten respondents $(26 \%)$. Based on the score category, it can be seen that the level of application of Google Classroom from 39 
students is 6 students (15\%) have a very high category, 17 students (44\%) have a high category, 11 students $(28 \%)$ have a moderate category, while those who have a low category as many as five students (13\%) and none of them were in the very low category. By looking at the mean (M) score (64.23), the variable score category for the application of Google Classroom, it can be said that the score for the application of Google Classroom for the twelfth-grade students of RPL SMK Negeri 3 Pariaman is in the high category.

The learning motivation data were obtained from a questionnaire consist of 25 statement items with five alternative answers, 5 for the highest score and 1 for the lowest score. The data obtained from the questionnaire for the learning motivation variable showed that the highest score is 104 from the highest possible score of 125 . The lowest score is 60 , from the lowest possible score of 25 . The results of the analysis using the IBM SPSS Statistics 24 application show a mean (M) of 78.05; median (Me) of 80, mode (Mo) of 60, and standard deviation (SD) of 12.004. The frequency distribution shows that the greatest frequency for learning motivation scores is 60-66 intervals of 10 respondents $(26 \%)$. Based on the score category, it can be seen that the level of learning motivation of 39 students is one student (3\%) has a very high category, 15 students (38\%) have a high category, 13 students $(33 \%)$ have a moderate category. In comparison, those who have a low category are ten students $(26 \%)$. None were in the very low category. By looking at the mean (M) score (78.05), the variable score category of learning motivation, it can be said that the score for the twelfth-grade student learning motivation of RPL SMK Negeri 3 Pariaman is in the medium category.

Student learning outcomes data were obtained from the documentation of the final grades of knowledge competency in the first semester of TP. 2020/2021 results of average assignment grade, daily assessment, and mid-semester assessment. The data obtained showed that the highest score is 85 and the lowest score is 75 . The results of the analysis using the IBM SPSS Statistics 24 application show a mean (M) of 78.74; median (Me) of 79 , mode (Mo) of 79, and standard deviation (SD) of 2.468. The frequency distribution shows that the greatest frequency for learning outcomes scores is at intervals of 77-78 consists of 11 students (28\%), and intervals of 7980 consist of 11 students (28\%). Based on the score category, it can be seen that the level of learning outcomes of 39 students is that all students $(100 \%)$ have a very high category. By looking at the mean score $(\mathrm{M})$ of 78.74 categories of learning outcomes variable scores, it can be said that the scores for the twelfth-grade student learning outcomes of RPL SMK Negeri 3 Pariaman are included in the very high category.

The normality test was carried out to determine whether the data for each variable was normally distributed or not. The normality test was carried out by the One Sample Kolmogorov Smirnov method. The results of the normality test for each variable are as follows:

Table 1. Normality Test Results

\begin{tabular}{llll}
\hline No & Variable & Significance & Information \\
\hline 1. & Google Classroom implementation & 0,200 & Normal \\
2. & Motivation to learn & 0,690 & Normal \\
3. & Learning outcomes & 0,126 & Normal \\
\hline
\end{tabular}

Based on table 1, the normality test results can be concluded that all data for each variable was normally distributed. The significance score of all research variables is greater than 0.05 . A linearity test was performed to determine the linearity of the data, whether two variables have a linear relationship or not. The test uses the Test for Linearity at the 0.05 significance level. The results of the linearity test on each of the independent variables with the dependent variable are as follows:

Table 2. Linearity Test Results

\begin{tabular}{llllll}
\hline \multirow{2}{*}{ No } & \multirow{2}{*}{ Variable } & \multirow{2}{*}{ Significance } & F Score & Information \\
\cline { 4 - 5 } & & & Count & Table & \\
\hline 1. & $\mathrm{X} 1-\mathrm{Y}$ & 0,214 & 1,554 & 2,50 & Linear \\
2. & $\mathrm{X} 2-\mathrm{Y}$ & 0,382 & 1,550 & 2,18 & Linear \\
\hline
\end{tabular}

Based on table 2, the results of the linearity test can be concluded that:

a. The variable of applying Google Classroom to learning outcomes score is 0.214 , more than 0.05 . The calculated F score is 1.554 smaller than F table 2.50 at the $5 \%$ significance level, so it can be concluded that there is a linear relationship between the variables of Google Classroom's application to learning outcomes.

b. The learning motivation variable on learning outcomes is 0.382 , more than 0.05 . The calculated $\mathrm{F}$ score is 1.550 smaller than F table 2.18 at the $5 \%$ significance level, so it can be concluded that there is a linear relationship between the learning motivation variable on learning outcomes. 
The multicollinearity test was conducted to determine the presence or absence of multicollinearity, a condition in the regression model with a perfect or near-perfect correlation between the independent variables. The multicollinearity test method used is by looking at the Tolerance and Variance Inflation Factor (VIF) scores. The multicollinearity test results between independent variables are as follows:

Table 3. Multicollinearity Test Results

\begin{tabular}{lllll}
\hline No & Independent Variable & Tolerance Score & VIF Score & Information \\
\hline 1. & Google Classroom & 1,000 & 1,000 & Not Multicollinearity \\
2. & Motivation to learn & 1,000 & 1,000 & Not Multicollinearity \\
\hline
\end{tabular}

Based on table 3, multicollinearity testing results can be concluded that all independent variables have a Tolerance score of more than 0.1 and a VIF score of less than 10, so there is no multicollinearity between the independent variables so that the regression analysis can be continued. In the first hypothesis, the results of simple regression analysis can be stated as follows:

Table 4. Results of Simple Regression Analysis ( $\left.\mathrm{X}_{1}-\mathrm{Y}\right)$

\begin{tabular}{|c|c|c|c|c|c|c|}
\hline \multirow{2}{*}{ Variable } & \multicolumn{2}{|c|}{ r Score } & \multirow{2}{*}{ Constant (a) } & \multirow{2}{*}{$\begin{array}{l}\text { Regression } \\
\text { Coefficient (b) }\end{array}$} & \multicolumn{2}{|l|}{ t score } \\
\hline & $\mathbf{r} \mathrm{X}_{1} \mathrm{Y}$ & r table & & & t count & t table \\
\hline $\begin{array}{ll}\mathrm{X}_{1} & \mathrm{Y}\end{array}$ & 0,514 & 0,325 & 71,955 & 0.106 & 3,648 & 2,026 \\
\hline
\end{tabular}

Based on table 4 , the regression equation can be stated as follows: $\widehat{Y}=71,955+0,106 X_{1}$. This equation shows that the $\mathrm{X}_{1}$ correlation coefficient's score is 0.106 , which means that if the application of Google Classroom increases by 1 point, it will be followed by an increase in points for web programming learning outcomes 0.106. The simple regression significance test aims to determine the significance of Google Classroom's application $\left(\mathrm{X}_{1}\right)$ on learning outcomes $(\mathrm{Y})$. This significance test uses the t-test. The criteria used if $\mathrm{t}$ count $>\mathrm{t}$ table then contribute significantly and vice versa. Based on the results of the $\mathrm{t}$-test, the $\mathrm{t}$ score is 3,648 . Compared with the $\mathrm{t}$ table score of 2.026 at the $5 \%$ significance level, the $\mathrm{t}$ score is greater than the $\mathrm{t}$ table. Ho is rejected, and $\mathrm{Ha}$ is accepted, so it can be said that there is a positive and significant contribution between the application of Google Classroom to the learning outcomes of subjects twelfth-grade student web programming RPL at SMK Negeri 3 Pariaman, then the first hypothesis can be accepted. In the second hypothesis, the results of simple regression analysis can be stated as follows:

Table 5. Results of Simple Regression Analysis $\left(\mathrm{X}_{2}-\mathrm{Y}\right)$

\begin{tabular}{|c|c|c|c|c|c|c|}
\hline \multirow{2}{*}{ Variable } & \multicolumn{2}{|c|}{ r score } & \multirow{2}{*}{ Constant (a) } & \multirow{2}{*}{$\begin{array}{l}\text { Regression } \\
\text { Coefficient (b) }\end{array}$} & \multicolumn{2}{|l|}{ t score } \\
\hline & $\mathbf{r} \mathrm{X}_{2} \mathrm{Y}$ & r table & & & t count & t table \\
\hline $\begin{array}{ll}\mathrm{X}_{2} & \mathrm{Y} \\
\end{array}$ & 0,425 & 0,325 & 71,923 & 0.087 & 2,856 & 2,026 \\
\hline
\end{tabular}

Based on table 5, the regression equation can be stated as follows: $\widehat{Y}=71,923+0,087 \mathrm{X}_{2}$ This equation shows that the score of the correlation coefficient $X_{2}$ is 0.087 , which means that if the application of learning motivation increases by 1 point, it will be followed by an increase in points for learning outcomes of web programming by 0.087 . Simple regression significance testing aims to determine the significance of learning motivation (X2) on learning outcomes (Y). This significance test uses the t-test. The criteria used if $t$ count $>\mathrm{t}$ table then contribute significantly and vice versa. Based on the results of the $\mathrm{t}$-test, the $\mathrm{t}$ score is 2.856 . When compared with the $t$ table score of 2.026 at a significance level of 5\%, the $t$ score is greater than the $t$ table. $\mathrm{Ho}$ is rejected, and $\mathrm{Ha}$ is accepted. It can be said that there is a positive and significant contribution between learning motivation and learning outcomes in programming subjects class XII RPL student at SMK Negeri 3 Pariaman, then the second hypothesis can be accepted. In the third hypothesis, the results of multiple regression analysis can be stated as follows: 
Table 6. Results of Multiple Regression Analysis $\left(\mathrm{X}_{1} \mathrm{X}_{2}-\mathrm{Y}\right)$

\begin{tabular}{|c|c|c|c|c|c|c|c|c|}
\hline \multirow{2}{*}{\multicolumn{2}{|c|}{ Variable }} & \multicolumn{2}{|l|}{ R score } & \multirow[t]{2}{*}{ Constant (a) } & \multicolumn{2}{|c|}{$\begin{array}{l}\text { Regression } \\
\text { Coefficient }\end{array}$} & \multicolumn{2}{|l|}{ F score } \\
\hline & & $\mathbf{R} \mathrm{X}_{1} \mathrm{X}_{2} \mathrm{Y}$ & R table & & b1 & b2 & F count & F table \\
\hline $\mathrm{X}_{1} \mathrm{X}_{2}$ & $\mathrm{Y}$ & 0,670 & 0,325 & 71,955 & 0,106 & 0,088 & 14,662 & 3,259 \\
\hline
\end{tabular}

Based on table 6 , the regression equation can be stated as follows $\widehat{\mathrm{Y}}=65,018+0,106 \mathrm{X}_{1}+0,88 \mathrm{X}_{2}$. This equation shows that the $\mathrm{X} 1$ correlation coefficient's score is 0.106 , which means that if the application of Google Classroom increases by 1 point, it will be followed by an increase in points for learning outcomes of web programming 0.106 . The correlation coefficient $\mathrm{X}_{2}$ is 0.88 , which means that if learning motivation increases by 1 point, it will be followed by an increase in points for learning outcomes of web programming by 0.88 .

From the results of multiple regression analysis, the $\mathrm{R}$ count is reached by a rate of 0.670 . The coefficient of determination $\left(R^{2}\right)$ is 0.449 . The coefficient of determination $\left(R^{2}\right)$ is a tool to measure all independent variables' influence on the dependent variable. The results of this $\mathrm{R}^{2}$ indicate that the magnitude of the influence of the application of Google Classroom and learning motivation together on student learning outcomes is $49.9 \%$. At the same time, other factors or variables influence the remaining $50.1 \%$.

The multiple regression significance tests aim to determine the significance of the application of Google Classroom $\left(\mathrm{X}_{1}\right)$ and learning motivation $\left(\mathrm{X}_{2}\right)$ on learning outcomes $(\mathrm{Y})$. This significance test uses the $\mathrm{F}$ test. The criteria used if $\mathrm{F}$ count $>\mathrm{F}$ table then it contributes significantly and vice versa. Based on the results of the $\mathrm{F}$ test, the calculated F score is 14.662. When compared with the F table score of 3.259 at the 5\% significance level, then the calculated F score is greater than the F table so that it can be said that there is a positive and significant contribution to the application of Google Classroom and learning motivation together on learning outcomes in Web Programming subjects. Twelfth-grade students of RPL at SMK Negeri 3 Pariaman, then the third hypothesis can be accepted.

Based on the research results that have been described, several findings can be described, first, there is a positive and significant contribution between the application of Google Classroom to the learning outcomes of the twelfth-grade students of RPL web programming at SMK Negeri 3 Pariaman. The use of google classroom is one of the solutions offered in online learning today. Google Classroom is an online learning application that can be used by all spheres of education that helps teachers and students share files in teaching and learning activities (Mahitsa \& Mahardini, 2020). Google Classroom combines Google Drive for assignment creation and distribution, Google Docs, Sheets, Slides for writing, Gmail for communications, Google Calendar for scheduling, and Google Meet for video conferencing (Mahitsa \& Mahardini, 2020). Learning with Google classrooms can allow teachers and students to learn by combining face-to-face and face-to-face learning. With a combination of these two methods, learning will certainly be more effective. Google classroom is effectively applied in the learning process and positively affects mathematical thinking skills (Santosa et al., 2020). Rahmanto \& Bunyamin, (2020) stated that Google Classroom is effectively used in educational administration practicum subjects because students and lecturers are easy to access according to lecture needs.

Second, there is a positive and significant contribution between learning motivation and learning outcomes of the twelfth-grade students of RPL at SMK Negeri 3 Pariaman to accept the second hypothesis. Learning motivation is one factor that affects learning outcomes because motivation can increase student activity in the learning process. Motivation to learn is an impulse that allows students to act or do something (Mulyasih \& Suryani, 2016). Motivation to learn is necessary for learning to be actively involved in learning and make it easier for students to understand the material (Pratiwi et al., 2019; Sjukur, 2013). Maximizing motivation will maximize the learning outcomes that can be achieved (Shaleh, 2016). Motivation can play a role in strengthening learning if a child who is learning is faced with a problem that determines the solution and can only be solved thanks to the help of things that have been passed (Novianti et al., 2020). Learning motivation has a positive and significant relationship with student learning outcomes (Saputra et al., 2018). The role of the teacher here is very influential on student learning motivation. The main factor is the key to success in the learning process (Prananda \& Hadiyanto, 2019).

Third, there is a positive and significant contribution to the implementation of Google Classroom and learning motivation together on the learning outcomes of the twelfth-grade students of RPL at SMK Negeri 3 Pariaman. Together, the application of Google Classroom and learning motivation contribute to learning outcomes. It can be said that implementing a learning method that activates students in the learning process will arouse students' desire to learn and, of course, will encourage students to be more active in the learning process. With more active learning dominated by students, making learning more meaningful. Meaningful learning will be generated if students gain experience and develop emotional intelligence. The learning process is carried out with a constructive approach (Angela, 2014; Kostiainen et al., 2018). Children can obtain experience through 
problem-solving activities or activities carried out by a scientific process to produce evidence of social life experiences' learning process.

\section{Conclusion}

Based on the results of the research and discussion previously described, the following conclusions are obtained. There is a positive and significant contribution to the application of Google Classroom and learning motivation to the learning outcomes of the twelfth-grade students of RPL web programming at SMK Negeri 3 Pariaman. Learning with google classrooms provides students opportunities to increase student motivation to be more active in the learning process, impacting learning outcomes.

\section{References}

Angela, T. (2014). Challenges to Meaningful Learning in Social Studies - The Key Competences as an Opportunity to Students' Active Participation. Procedia - Social and Behavioral Sciences, 128, 192 197. https://doi.org/10.1016/j.sbspro.2014.03.142

Anugrahana, A. (2020). Hambatan, Solusi dan Harapan : Pembelajaran Daring Selama Masa Pandemi Covid-19 Oleh Guru Sekolah Dasar. Scholaria: Jurnal Pendidikan Dan Kebudayaan, 10(3), 282-289. https://ejournal.uksw.edu/scholaria/article/view/4033

Arnott, L., \& Yelland, N. (2020). Multimodal lifeworlds: Pedagogies for play inquiries and explorations. Journal of Early Childhood Education Research, 9(1), 124-146.

Chang, T. Y., Hong, G., Paganelli, C., Phantumvanit, P., Chang, W. J., Shieh, Y. S., \& Hsu, M. L. (2020). Innovation of dental education during COVID-19 pandemic. Journal of Dental Sciences, 155. https://doi.org/10.1016/j.jds.2020.07.011

Cynthia, L. C., Martono, T., \& Indriayu, M. (2015). Pengaruh Fasilitas Belajar dan Motivasi Belajar Terhadap Prestasi Belajar Mata Pelajaran Ekonomi Siswa Kelas XI IIS di SMA Negeri 5 Surakarta Tahun Ajaran 2015/2016. Jurnal Pendidikan Bisnis Dan Ekonomi, 01(02), 1-20. http://jurnal.fkip.uns.ac.id/index.php/ptn/article/view/7397/5169

Daheri, M., Juliana, Deriwanto, \& Amda, A. D. (2020). Efektifitas WhatsApp sebagai Media Belajar Daring. Jurnal Basicedu, 3(2), 524-532. https://doi.org/10.31004/basicedu.v4i4.445

Edwards, S., Skouteris, H., Rutherford, L., \& Cutter-Mackenzie, A. (2012). 'It's all about Ben10 ${ }^{\mathrm{TM}}$ ': Children's play, health and sustainability decisions in the early years. ,. Early Child Development and Care, 183(2), 280-293. https://doi.org/https://doi.org/10.1080/03004430. 2012.671816.

Hwang, G. J., Wang, S. Y., \& Lai, C. L. (2020). Effects of a social regulation-based online learning framework on students' learning achievements and behaviors in mathematics. Computers and Education, 160, 104031. https://doi.org/10.1016/j.compedu.2020.104031

Khachfe, H. H., Chahrour, M., Sammouri, J., Salhab, H. A., Makki, B. E., \& Fares, M. Y. (2020). An Epidemiological Study on COVID-19: A Rapidly Spreading Disease. Cureus, 12(3). https://doi.org/10.7759/cureus.7313

Kkese, E. (2020). McGurk effect and audiovisual speech perception in students with learning disabilities exposed to online teaching during the COVID-19 pandemic. Medical Hypotheses, 144(July), 110233. https://doi.org/10.1016/j.mehy.2020.110233

Kostiainen, E., Ukskoski, T., Ruohotie-Lyhty, M., Kauppinen, M., Kainulainen, J., \& Mäkinen, T. (2018). Meaningful learning in teacher education. Teaching and Teacher Education, 71, 66-77. https://doi.org/10.1016/j.tate.2017.12.009

Lage-Cala, S., Folgueras-Díaza, M. B., Alonso-Hidalgoa, M., García-Menéndezb, D., \& Fernández-Garcíab, F. J. (2020). Investigation of the effectiveness of online learning tools for energy performance certificates preparation. Energy Reports, 6, 609-614. https://doi.org/10.1016/j.egyr.2019.09.034

Mahitsa, M., \& Mahardini, A. (2020). Analisis Situasi Penggunaan Google Classroom pada Pembelajaran Daring Fisika. Jurnal Pendidikan $\quad$ FIsika, $215-224$. https://doi.org/http://dx.doi.org/10.24127/jpf.v8i2.3102 ANALISIS 
Mishra, D. L., Gupta, D. T., \& Shree, D. A. (2020). Online Teaching-Learning in Higher Education during Lockdown Period of COVID-19 Pandemic. International Journal of Educational Research Open, August, 100012. https://doi.org/10.1016/j.ijedro.2020.100012

Mulyasih, P. S., \& Suryani, N. (2016). Pengaruh Disiplin Belajar, Lingkungan Keluarga, Dan Motivasi Belajar Terhadap Prestasi Belajar Mata Pelajaran Pengantar Administrasi. Economic Education Analysis Journal, 5(2), 602-602. https://doi.org/http://journal.unnes.ac.id/sju/index.php/eea

Novianti, C., Sadipun, B., \& Balan, J. M. (2020). Pengaruh Motivasi Belajar terhadap Hasil Belajar Matematika Peserta Didik. Science and Phich Education Jurnal, 3(2). https://doi.org/https://doi.org/10.31539/spej.v3i2.992 PENGARUH

O’Doherty, D., Dromey, M., Lougheed, J., Hannigan, A., Last, J., \& McGrath1, D. (2018). Barriers and solutions to online learning in medical education - an integrative review. BMC Medical Education, 18(130), 1-11. https://doi.org/https://doi.org/10.1186/s12909-018-1240-0

Oyedotun, T. D. (2020). Sudden change of pedagogy in education driven by COVID-19: Perspectives and evaluation from a developing country. Research in Globalization, 2(June), 100029. https://doi.org/10.1016/j.resglo.2020.100029

Panesar, K., Dodson, T., Lynch, J., Bryson-Cahn, C., Chew, L., \& Dillon, J. (2020). Evolution of COVID-19 Guidelines for University of Washington Oral and Maxillofacial Surgery Patient Care. Journal of Oral and Maxillofacial Surgery, 78(7), 1136-1146. https://doi.org/10.1016/j.joms.2020.04.034

Patricia, A. (2020). College Students' Use and Acceptance of Emergency Online Learning Due to COVID-19. International Journal of Educational Research Open, 100011. https://doi.org/10.1016/j.ijedro.2020.100011

Permata, A., \& Bhakti, Y. B. (2020). Keefektifan Virtual Class dengan Google Classroom dalam Pembelajaran Fisika Dimasa Pandemi Covid-19. JIPFRI (Jurnal Inovasi Pendidikan Fisika Dan Riset Ilmiah), 4(1), 27-33. https://doi.org/10.30599/jipfri.v4i1.669

Prananda, G., \& Hadiyanto. (2019). Korelasi Antara Motivasi Belajar Dengan Hasil Belajar Siswa Dalam Pembelajaran IPA Di Sekolah Dasar. Jurnal Basicedu, 3(3), 524-532. https://doi.org/https://doi.org/10.31004/basicedu.v3i3.181

Pratiwi, N. D., Agustin, F., \& Widyaningrum, A. (2019). Pengaruh motivasi belajar pada Penerapan model kooperatif tipe team Assisted individualization (TAI) terhadap hasil belajar IPA siswa kelas III SD Negeri Puri 03 Pati. Jurnal Refleksi Pembelajaran, 4(1), 9-13. https://ejurnalkotamadiun.org/index.php/JRP/article/view/270

Rahmanto, M. A., \& Bunyamin. (2020). Efektivitas media pembelajaran daring melalui Google Classroom. Jurnal Pendidikan Islam, 11(November), $119-135$. https://doi.org/https://doi.org/10.22236/jpi.v11i2.5974

Remuzzi, A., \& Remuzzi, G. (2020). COVID-19 and Italy: what next? The Lancet, 395(10231), 1225-1228. https://doi.org/10.1016/S0140-6736(20)30627-9

Roh, Y. S., Jang, K. I., \& Issenberg, S. B. (2020). Nursing students' perceptions of simulation design features and learning outcomes: The mediating effect of psychological safety. Collegian, 2-7. https://doi.org/10.1016/j.colegn.2020.06.007

Sahu, P. (2020). Closure of Universities Due to Coronavirus Disease 2019 (COVID-19): Impact on Education and Mental Health of Students and Academic Staff. Cureus, 2019(4), 4-9. https://doi.org/10.7759/cureus.7541

Santosa, F. H., Negara, H. R. P., \& Samsul Bahri. (2020). Efektivitas Pembelajaran Google Classroom Terhadap Kemampuan Penalaran Matematis Siswa. Jurnal Pemikiran Dan Penelitian Pendidikan Matematika (JP3M), 3(1), 62-70. https://doi.org/10.36765/jp3m.v3i1.254

Saputra, H. D., Ismet, F., \& Andrizal, A. (2018). Pengaruh Motivasi Terhadap Hasil Belajar Siswa SMK. INVOTEK: Jurnal Inovasi Vokasional Dan Teknologi, 18(1), 25-30. https://doi.org/10.24036/invotek.v18i1.168

Shaleh, M. (2016). Pengaruh Motivasi, Faktor Keluarga, Lingkungan Kampus Dan Aktif Berorganisasi Terhadap Prestasi Akademik. Phenomenon: Jurnal Pendidikan MIPA, 4(2), 109. https://doi.org/10.21580/phen.2014.4.2.122 
Sjukur, S. B. (2013). Pengaruh blended learning terhadap motivasi belajar dan hasil belajar siswa di tingkat SMK. Jurnal Pendidikan Vokasi, 2(3), 368-378. https://doi.org/10.21831/jpv.v2i3.1043

Sourial, N., Longo, C., Vedel, I., \& Schuster, T. (2018). Daring to draw causal claims from non-randomized studies of primary care interventions. Family Practice, 35(5), 639-643. https://doi.org/10.1093/fampra/cmy005

Wong, G. L. H., Wong, V. W. S., Thompson, A., Jia, J., Hou, J., Lesmana, C. R. A., Susilo, A., Tanaka, Y., Chan, W. K., Gane, E., Ong-Go, A. K., Lim, S. G., Ahn, S. H., Yu, M. L., Piratvisuth, T., \& Chan, H. L. Y. (2020). Management of patients with liver derangement during the COVID-19 pandemic: an AsiaPacific position statement. The Lancet Gastroenterology and Hepatology, 5(8), 776-787. https://doi.org/10.1016/S2468-1253(20)30190-4

Wulandari, E. T. (2019). Pentingnya Pengaruh Fasilitas Belajar Terhadap Prestasi Belajar Siswa The Importance of the Effect of Learning Facilities on Student Learning Achievement. EProsiding Seminar Nasional Biologi VI, 20, 258-261. 